\title{
Sistem Kendali Nutrisi Hidroponik berbasis Fuzzy Logic berdasarkan Objek Tanam
}

\section{FITRIA SURYATINI, SUHARYADI PANCONO, SUSETYO BAGAS BHASKORO, PUTRI MUTHIA SARASWATI MULJONO}

\author{
Jurusan Teknik Otomasi Manufaktur dan Mekatronika, Politeknik Manufaktur \\ Bandung, Indonesia \\ Email: fitriasuryatini88@gmail.com
}

Received 7 Mei 2020 | Revised 2 Agustus 2020| Accepted 20 Oktober 2020

\begin{abstract}
ABSTRAK
Hidroponik merupakan sistem pertanian yang menggunakan air sebagai media tanam sehingga tidak memerlukan media tanah ataupun area luas. Hidroponik memerlukan perlakuan khusus seperti menjaga kadar nutrisi dalam rentangnya sehingga penggunaan sistem kendali dapat mempermudah pemantauan dan pengaturan parameter. Sistem kendali yang digunakan adalah fuzzy logic mamdani dengan input offset kadar nutrisi dan level air, serta output durasi nyala motor pompa nutrisi dan air untuk mencapai set point yang dapat ditentukan melalui antarmuka berdasarkan database objek tanam atau slider manual. Hasil penelitian menunjukkan nilai keberhasilan sebesar 95,14\% untuk kendali nutrisi dan 91,64\% untuk kendali level air dalam mencapai set point, serta menghasilkan pertumbuhan tanaman yang lebih baik, dimana rata-rata penambahan tinggi antara sistem dengan dan tanpa kendali nutrisi memiliki perbedaan sebesar 1,96 cm.
\end{abstract}

Kata kunci: sistem kendali, fuzzy logic, IoT, hidroponik, nutrisi

\begin{abstract}
Hydroponic is a farming system which uses water as planting media, so it is unnecessary to use soil nor consume wide area. Hydroponic requires special handlings such as maintaining nutrient measurement level within range so the use of control system may ease the parameter monitoring and control. The control system that is used is mamdani fuzzy logic with the nutrient measurement level offset and water level input, as well as nutrient and water pump motors activation duration output to reach the set point determined from the interface based on the planting-object database or manual slider. The results showed a success value of $95.14 \%$ for nutritional control and $91.64 \%$ for water level control in reaching set point, and resulting in better plant growth, where the average increase in height between the system with and without nutrient control has a difference of $1.96 \mathrm{~cm}$.
\end{abstract}

Keywords: control system, fuzzy logic, IoT, hydroponics, nutrient 
Suryatini, dkk

\section{PENDAHULUAN}

Hidroponik merupakan sistem pertanian yang menggunakan air sebagai media tanam. Hidroponik digunakan di lingkungan pertanian maupun lingkungan rumah. Hidroponik tidak membutuhkan media tanah ataupun area yang luas sehingga dijadikan alternatif dari pertanian konvensional. Hidroponik juga dapat digunakan pada musim hujan maupun kemarau secara kontinu, tidak seperti pertanian konvensional yang hanya dapat bercocok tanam pada musim tertentu. Namun, bertani menggunakan sistem hidroponik juga memiliki tantangan tersendiri untuk dilakukan. Hidroponik memerlukan perlakuan khusus terkait berbagai parameter untuk memberi hasil panen yang optimal dengan kualitas baik. Salah satu parameter yang perlu diperhatikan pada hidroponik adalah nutrisi.

Nutrisi harus terus dipantau dan terus dipertahankan sesuai rentang nutrisi yang dibutuhkan tanaman. Kurangnya nutrisi dapat menyebabkan antara lain daun tua kuning dan kisut, daun menggulung, daun belang-belang, ataupun daun berjamur. Sementara kelebihan nutrisi dapat menyebabkan antara lain daun hijau tua, ataupun terhambatnya pematangan buah. Setiap kelompok tanaman memiliki rentang kebutuhan nutrisi yang berbeda-beda. Perlakuan tersebut mengkonsumsi waktu yang tidak sedikit. Masyarakat yang sibuk dengan pekerjaan dan kegiatan, dekat maupun jauh dari lokasi hidroponik, seringkali kesulitan memantau dan mempertahankan kandungan nutrisi tersebut. Petani yang memiliki perkebunan di berbagai wilayah yang berjauhan pun akan kesulitan untuk memantau kandungan nutrisi tersebut. Pengendali otomatis yang diatur dan dipantau secara jarak jauh diperlukan untuk mengatasi permasalahan tersebut.

Pengendalian sistem hidroponik telah dilakukan oleh peneliti terdahulu dengan berbagai metode. Sistem pengendalian hidroponik menggunakan metode PID diterapkan pada pengendalian nutrisi (Akbar, dkk, 2016), dan pada pengendalian temperatur dikombinasikan dengan metode on/off pada pengendalian kelembaban, $\mathrm{pH}$, dan EC (Puspasari, dkk, 2018). Metode lain yang digunakan dalam pengendalian sistem hidroponik adalah fuzzy logic control sebagai salah satu advanced algorithms (Pakzad \& Pakzad, 2018). Penelitian Fuzzy Logic Control untuk mengatur nutrisi pada sistem hidroponik berdasarkan Electrical Conductivity (EC) dengan input fuzzy yang digunakan adalah EC error dan kedalaman air untuk menentukan lama penyalaan valve nutrisi yang menunjukkan hasil bahwa kontrol logika fuzzy dapat mempertahankan rentang nilai EC sesuai dengan kebutuhan tanaman (Mashumah, dkk, 2018) (Heliadi, dkk, 2018). Berdasarkan penelitian terdahulu, pengendalian suhu pada hidroponik menggunakan kendali fuzzy logic mencapai rise time lebih cepat tetapi memiliki overshoot yang lebih besar dari kendali PID (Triwidyastuti dkk, 2018). Nilai error kendali fuzzy logic lebih kecil dari nilai error kendali PID (Ibrahim, dkk, 2015). Selain itu, penelitian terdahulu yang menggunakan kendali fuzzy logic menyimpulkan bahwa time response dari sistem dapat dipengaruhi oleh selisih nilai pembacaan kadar nutrisi berupa Electrical Conductivity (EC) dengan rentang target, nilai Pulse Width Modulation (PWM) pompa, durasi pembacaan sensor, dan delay dari komunikasi IoT (Yolanda, dkk, 2017). Kemudian berdasarkan penelitian terdahulu yang tidak menggunakan pengaduk sirkulasi larutan pada bak pencampuran, kendali nutrisi menggunakan fuzzy logic berhasil dilakukan untuk menjaga nilai EC dengan total rise time dan settling time yang dapat mencapai lebih dari 20 menit (Safura, dkk, 2018).

Kendali otomatis untuk menjaga nilai nutrisi dapat menghasilkan nilai error sehingga pengaturan manual melalui antarmuka juga diperlukan untuk mengatasi keadaan error yang melebihi rentang nutrisi setelah proses pencampuran (Ruengittinun, dkk., 2017). Internet of Things (IOT) diimplementasikan untuk melakukan monitoring dan pengontrolan parameter- 
parameter, termasuk nutrisi pada plant hidroponik dapat membantu petani untuk meningkatkan efektivitas dan efisiensi monitoring dan pengontrolan plant hidroponik (Crisnapati, dkk., 2017) (Setiawan, dkk., 2019) (Lukito \& Lukito., 2018) (Yolanda, dkk., 2018).

Berdasarkan permasalahan pada sistem hidroponik serta hasil kajian penelitian terdahulu, maka pada penelitian ini dirancang kendali nutrisi dan volume air pada larutan nutrisi sistem hidroponik menggunakan kendali logika fuzzy berdasarkan objek tanam berbasis IOT sehingga pemantauan dan pengontrolan secara manual maupun otomatis dapat dilakukan secara jarak jauh pada satu jenis atau beberapa objek tanam yang memiliki rentang nutrisi yang bersinggungan yang dapat diatur melalui aplikasi android.

\section{METODOLOGI PENELITIAN}

\subsection{Perancangan Umum Sistem}

Sistem yang dirancang merupakan plant hidroponik dengan kadar nutrisi dan level/ketinggian larutan nutrisi yang dapat dijaga sesuai set point menggunakan sistem kendali fuzzy logic mamdani. Set point tersebut dapat diatur melalui antarmuka berbasis IoT menggunakan aplikasi Blynk. Program antarmuka berbasis IoT digunakan sebagai media pemantauan dan pengontrolan. Pada fitur pemantauan, terdapat pembacaan sensor nutrisi, sensor ketinggian (level air), dan sensor pH. Pengaturan melalui database dapat memberikan pemilihan objek tanam yang disertai dengan set point nutrisi dan $\mathrm{pH}$ masing-masing objek tanam. Pengguna dapat mengatur set point dengan memilih objek tanam tunggal ataupun lebih dari satu objek tanam melalui database yang menyimpan data rentang nutrisi setiap objek tanam. Objek tanam berbeda yang bisa ditanam bersamaan memiliki rentang nutrisi dan rentang $\mathrm{pH}$ yang bersinggungan atau sama Sementara pengaturan set point melalui slider memperbolehkan pengguna untuk mengatur set point secara leluasa selama masih dalam rentang yang disediakan oleh slider. Sementara set point ketinggian larutan nutrisi tersebut bersifat konstan $110 \mathrm{~mm}$ atau volume $10 \mathrm{~L}$. Gambaran umum sistem ditunjukkan pada Gambar 1.

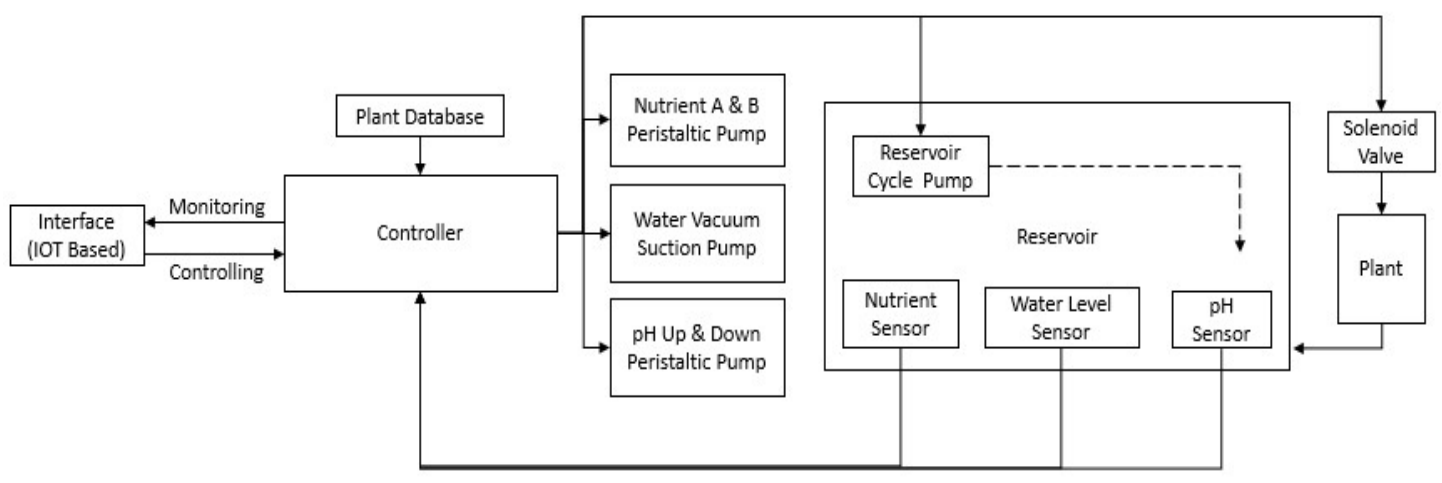

Gambar 1. Gambaran Umum Sistem

Controlleryang digunakan adalah mikrokontroler Arduino Mega. Controller berisikan program kendali sistem hidroponik dengan metode fuzzy logic Mamdani. Input fuzzy logic berupa offset pembacaan nutrisi dari set point dan pembacaan level air. Sementara output-nya berupa durasi aktuasi motor dari peristaltic pump, dengan debit $100 \mathrm{~mL} /$ Menit untuk menambahkan nutrisi A dan nutrisi B dengan volume yang sama, dan durasi aktuasi motor vacuum suction diaphragm pump dengan debit 2 L/Menit untuk menambahkan air. Controller juga mengendalikan aktivasi dan nonaktifnya peristaltic pump untuk $\mathrm{pH} u p, \mathrm{pH}$ down melalui 
aplikasi Blynk dan nyala matinya pompa reservoir serta solenoid valve. Selain itu, controller mengirimkan data pembacaan sensor serta status eksekusi proses pencampuran ke antarmuka. Fitur $\mathrm{pH}$ pada penelitian dibatasi oleh monitoring melalui antarmuka serta penambahan $\mathrm{pH}$ Up dan $\mathrm{pH}$ Down secara ON-OFF manual melalui push button pada antarmuka. Penelitian tidak meliputi kendali otomatis $\mathrm{pH}$.

Pembacaan kadar nutrisi dilakukan menggunakan sensor Total Dissolved Solids (TDS) SEN0244 DFRobot. Sedangkan Level air diukur menggunakan sensor ultrasonic HC-SRO4. Level air diperlukan untuk menghitung volume air, pada reservoir dengan panjang $378 \mathrm{~mm}$ dan lebar $241 \mathrm{~mm}$, sehingga kendali fuzzy logic dapat mengkalkulasikan durasi aktuasi motor pompa nutrisi dan air yang diperlukan untuk mencapai set point kadar nutrisi dan level air pada larutan nutrisi di dalam reservoir. Pompa yang digunakan memiliki dua output. Output pertama digunakan untuk memompa nutrisi ke tanaman. Sementara output kedua digunakan untuk melakukan sirkulasi pencampuran nutrisi setelah terjadi penambahan nutrisi dan atau air. Solenoid valve digunakan untuk mematikan penyiraman/penyaluran nutrisi ke tanaman selama pencampuran nutrisi dan air dilakukan.

\subsection{Perancangan Mekanik}

Domain mekanik mencakup struktur rangka dan elemen mekanik berupa aktuator yang bergerak untuk memberi perlakuan berdasarkan input yang diberikan. Perancangan rangka tersebut dilakukan dengan memerhatikan beberapa kriteria yang perlu dipenuhi. Penanaman menggunakan metode Nutrient Film Technique (NFT) harus memiliki aliran air yang tipis pada akar tanaman, maka alas penampang air harus rata dan tidak melengkung seperti pada metode Deep Flow Technique (DFT) dengan penampang setengah lingkaran. Kemudian Kemiringan talang NFT minimal 1 \% (Maulido, dkk, 2016). Selain itu, jarak antartanaman minimal $10 \mathrm{~cm}$ (Nugroho, 2017). Rancangan mekanik terdapat pada Gambar 2.

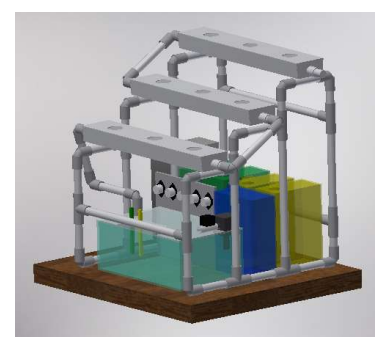

\section{Gambar 2. Rancangan Mekanik Plant Hidroponik}

Selain rancangan rangka pada domain mekanik, terdapat aktuator yang digunakan sebagai elemen mekanik utama pada sistem. Aktuator pada sistem tersebut adalah peristaltic pump. Peristaltic pump merupakan motor DC yang memiliki rotor yang melakukan mekanisme peristaltik terhadap selang untuk memompa fluida. Peristaltic pump pada umumnya memiliki tiga roda/rotor untuk memenuhi tiga stress points yang menyebabkan pengisapan dan pelepasan.

\subsection{Perancangan Elektronika}

Domain elektronika meliputi rangkaian seluruh komponen elektrik yang digunakan pada sistem. Rancangan tersebut meliputi rangkaian input, RTC, koneksi internet, dan rangkaian output. Pada rangkaian input, Sensor nutrisi (TDS) dan pH disambungkan ke input analog mikrokontroler, sementara sensor ultrasonik disambungkan ke dua input digital mikrokontroler untuk ECHO dan TRIGGER. Rangkaian output terdiri atas 4 peristaltic pump dan 1 vacuum suction diaphragm pump. Motor dari masing-masing pompa disambungkan ke pin digital. RTC 
disambungkan ke pin SCL dan SDA pada mikrokontroler. Rancangan umum domain elektronika ditunjukkan pada Gambar 3.

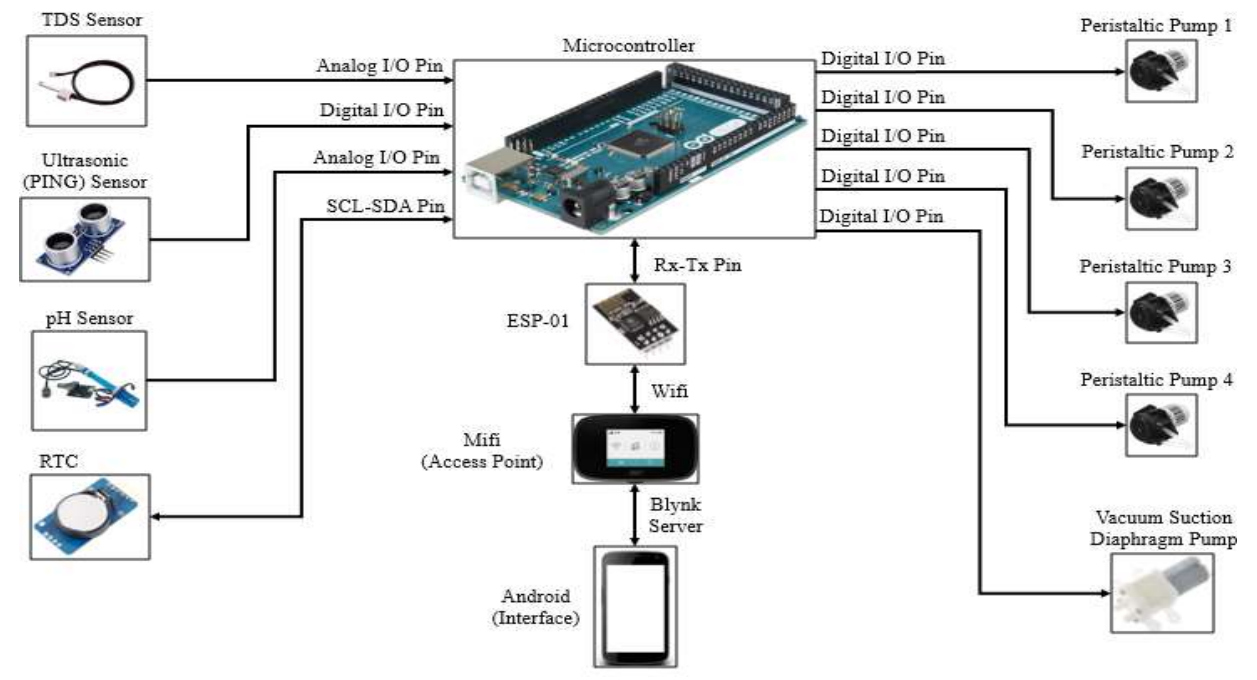

\section{Gambar 3. Rancangan Perangkat Elektronika}

Selanjutnya ESP-01, yang memiliki IC ESP8266, disambungkan ke mikrokontroler dengan memasang pin Rx dari ESP-01 ke pin Tx mikrokontroler dan pin Tx dari ESP-01 ke pin Rx mikrokontroler. ESP-01 tersebut bekerja sebagai Wi-fi shield sehingga mikrokontroler dapat menggunakan koneksi Wi-fi dari access point. Access point yang dipakai berupa Mifi. Access point tersebut digunakan agar sistem dapat dikoneksikan ke internet dan tersambung dengan server Blynk sehingga dapat menerima dan mengirim data ke antarmuka android melalui aplikasi Blynk.

\subsection{Perancangan Perangkat Lunak}

Domain perangkat lunak meliputi perancangan program kendali dan antarmuka. Pembuatan kendali melalui program dimulai dengan perancangan flowchart atau diagram alir kendali sistem yang terdapat pada Gambar 4. Pada sistem terdapat pilihan setting mode auto atau manual pada antarmuka. Mode manual memberikan pilihan untuk menyalakan dan mematikan pompa reservoir, solenoid valve pengalir ke tanaman, serta motor-motor penggerak peristaltic pump sesuai keinginan pengguna melalui tombol pada aplikasi. Tombol berupa ON-OFF toggle yang sekaligus memperlihatkan status aktuator yang sedang aktif atau nonaktif. Sedangkan mode auto ditunjukkan pada Gambar 4(b) dimulai dengan mengatur set point. Set point dapat diatur melalui slider atau database tanaman pada program. Slider memberikan pilihan untuk mengatur set point parameter nutrisi dan $\mathrm{pH}$ sesuai keinginan pengguna tetapi memiliki batas minimum dan maksimum pemilihan pada slider. Sementara set point melalui database dilakukan dengan memilih objek tanam dari daftar yang telah disediakan di antarmuka. Rentang parameter nutrisi dan $\mathrm{pH}$ akan ditentukan oleh database objek tanam terkait. Kemudian data set pointakan dikirim ke mikrokontroler oleh Blynkmelalui esp-01 sebagai wifishield.

Kendali otomatis menggunakan logika fuzzy dimulai dengan membaca parameter air dan nutrisi melalui sensor. Kemudian terjadi proses fuzzification dari data parameter yang didapat melalui sensor. Data tersebut dikonversi menjadi variabel linguistik melalui membership function. Selanjutnya dilakukan evaluasi melalui rules yang dibuat dan dilakukan proses deffuzification untuk mendapat data output. Data tersebut merupakan data durasi yang digunakan untuk mengontrol motor penggerak peristaltic pump untuk nutrisi dan vacuum 
suction diaphragm pump untuk air. Setelah itu terjadi proses pencampuran nutrisi selama 5 menit. Delay 5 menit tersebut ditentukan berdasarkan spesifikasi debit pompa pada reservoir untuk mengaduk campuran nutrisi. Pompa yang digunakan memiliki debit sebesar $1400 \mathrm{~L} / \mathrm{Jam}$. Set point default volume air adalah 10 Liter atau level air setinggi $110 \mathrm{~mm}$.

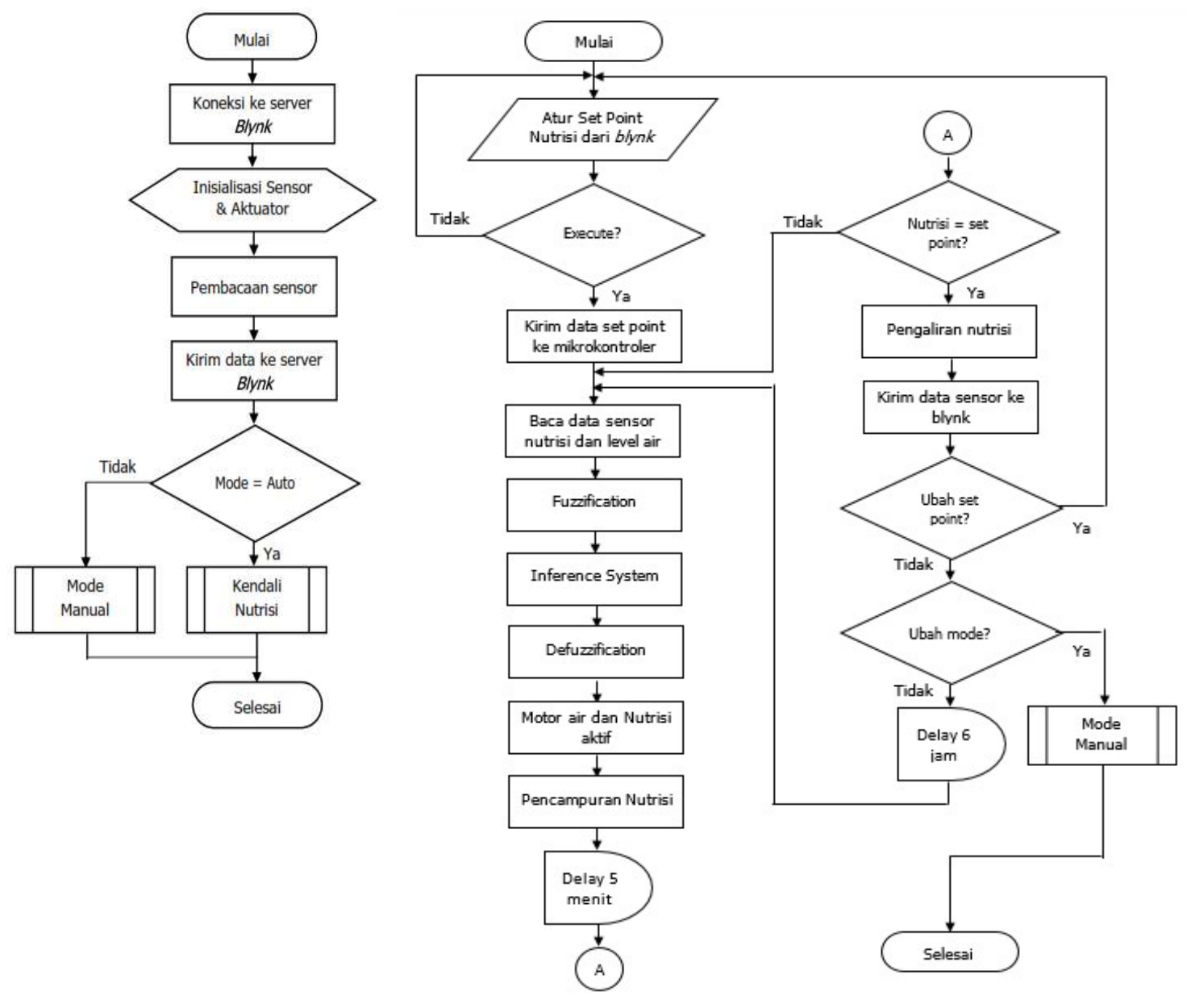

(a)

(b)

\section{Gambar 4. Diagram Alir Kendali Sistem (a) Kendali sistem keseluruhan dan (b) Kendali Otomatis menggunakan Logika Fuzzy}

Jika penyesuaian level air dan nutrisi sudah selesai, sensor akan membaca kembali parameter untuk dibandingkan dengan set point. Jika hasil kendali belum sesuai dengan set point, maka kendali fuzzy dilakukan kembali. Jika nutrisi sudah sesuai set point maka akan dilakukan pengaliran nutrisi dan data parameter yang dibaca oleh sensor akan dikirimkan ke antarmuka untuk monitoring dalam bentuk tampilan data real time serta grafik data. Jika tidak dilakukan perubahan set point atau perubahan mode maka sistem kendali fuzzy akan berulang secara otomatis setiap 6 jam.

\subsection{Perancangan Sistem Kendali Fuzzy Logic}

Sistem kendali fuzzy logic yang dirancang berupa sistem closed loop menggunakan model mamdani yang ditunjukkan pada Gambar 5. Input sistem berupa set point dari kadar nutrisi yang dikomparasikan dengan umpan balik kadar nutrisi untuk mendapat nilai offset/error kadar nutrisi sebagai salah satu input fuzzy. Umpan balik lainnya berupa ketinggian larutan 
berdasarkan volume (dengan panjang dan lebar yang konstan) yang digunakan pula sebagai input fuzzy. Kemudian aktuator yang digunakan pada sistem merupakan motor pompa nutrisi dan air yang diaktifkan berdasarkan output dari proses pengontrolan menggunakan fuzzy logic. Kedua aktuator tersebut dikomparasikan dan masuk ke plant reservoir yang mencakup volume larutan nutrisi sebagai output.

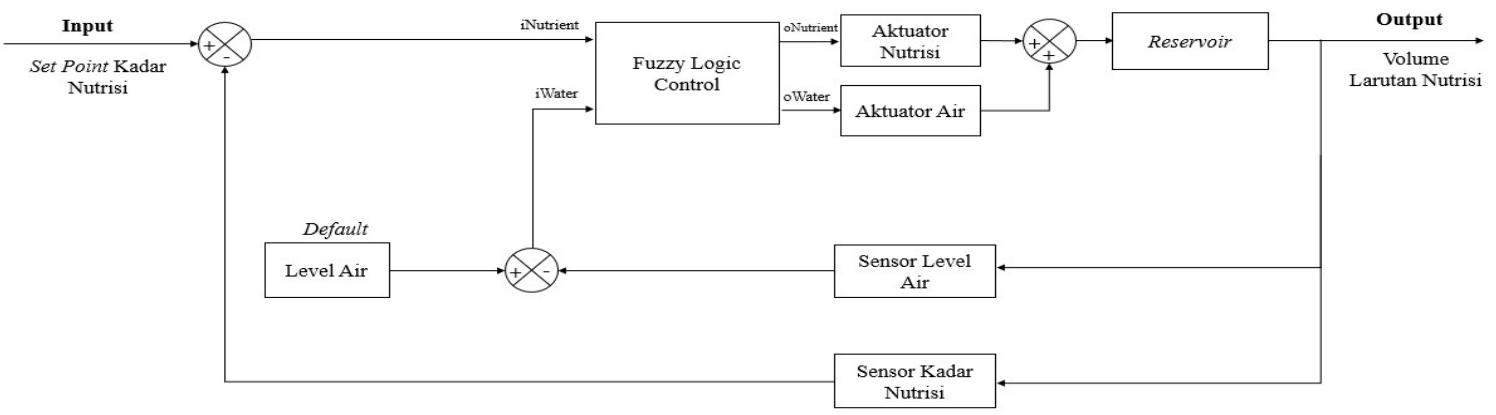

\section{Gambar 5. Blok Diagram Sistem}

Perancangan fuzzy logic dilakukan terlebih dahulu di perangkat lunak. Pengontrolan utama sistem menggunakan fuzzy logic untuk nutrisi dan level air. Metode fuzzy logic digunakan pada penelitian karena berdasarkan penelitian terdahulu, metode fuzzy menghasilkan error yang lebih kecil dibanding metode PID (Ibrahim, dkk, 2015). Berikut merupakan rancangan fuzzy logic menggunakan aplikasi "Control System Design and Analysis"di MatLab pada Gambar 6.
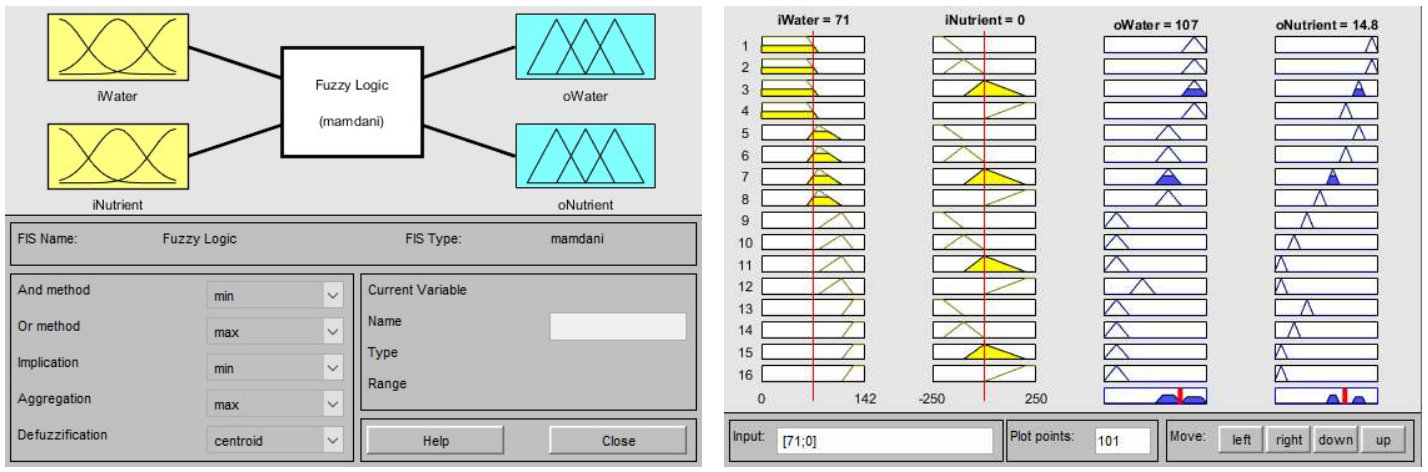

Gambar 6. Perancangan Fuzzy Logic pada Matlab

Kendali fuzzy yang dirancang terdiri dari dua input, yaitu iNutrient (pembacaan kadar nutrisi dari sensor TDS dalam satuan PPM) dan iWater (pembacaan level air dari sensor ultrasonik HC-SR04 dalam satuan mm). Membership input kadar nutrisi (iNutrient) berupa offset dari set point yang ditentukan berdasarkan adanya kondisi di mana kadar nutrisi sangat kurang dari set point $(\mathrm{L}=$ Low $)$, kurang dari set point $(\mathrm{M}=$ Medium), tepat pada set point $(\mathrm{E}=$ Enough), dan lebih dari set point $(\mathrm{H}=$ High). Membership input level air (iWater) ditentukan berdasarkan adanya kondisi air sedikit $(\mathrm{L}=$ Low $)$, sedang $(\mathrm{M}=$ Medium), cukup $(\mathrm{E}=$ Enough), dan banyak ( $\mathrm{H}=$ High). Membership function kadar nutrisi dan level air terdapat pada Gambar 7. 


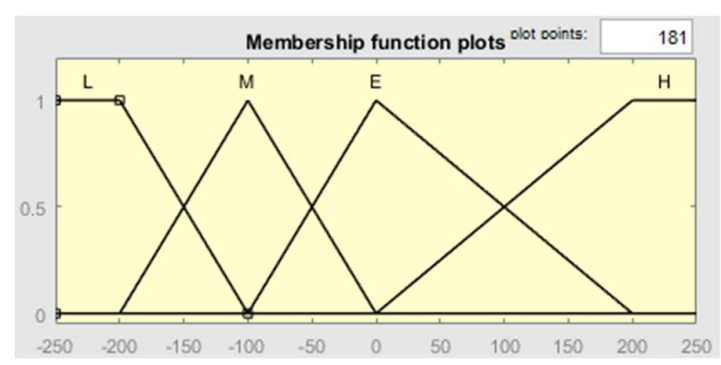

(a)

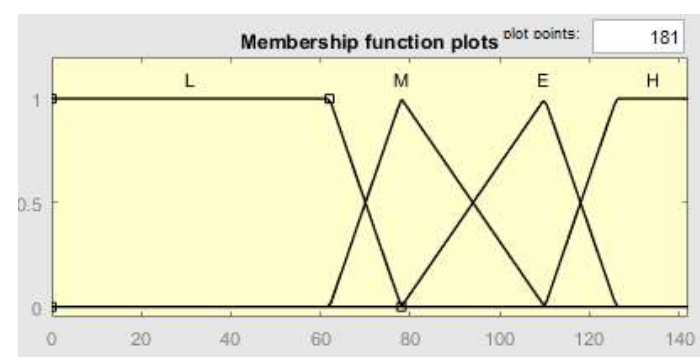

(b)

Gambar 7. Membership Function Input (a) PPM Nutrisi dan (b)Level Air

kendali fuzzy sistem ini memiliki dua buah output. Output pertama berupa durasi penyalaan peristaltic pump yang melakukan mekanisme peristaltik terhadap $\mathrm{AB}$ mix atau larutan nutrisi (oNutrient) dalam satuan detik. Penentuan membership output nutrisi dilakukan berdasarkan perhitungan jumlah nutrisi yang diperlukan untuk mencapai set point nutrisi. Perhitungan dilakukan berdasarkan spesifikasi debit peristaltic pump sebesar $100 \mathrm{~mL} /$ Menit. Maka untuk setiap 3 detik peristaltic pump menyala, $5 \mathrm{~mL}$ pekatan nutrisi A dan $5 \mathrm{~mL}$ pekatan nutrisi B akan ditambahkan ke reservoir. Kemudian penambahan nutrisi 0,5 $\mathrm{mL}$ pada 1 Liter air dapat meningkatkan kadar TDS pada air sebesar 100 PPM. Maka diperlukan $5 \mathrm{~mL}$ pekatan untuk meningkatkan 100 PPM air pada reservoir dengan set point 10 Liter air. Sehingga output nutrisi yang ditentukan berupa kelipatan 3 detik. Membership oNutrient terdiri dari Z = Zero, VVS = Very Very Small, VS = Very Small, S = Small, M = Medium, LG = Large, VLG = Very Large, dan VVLG = Very Very Large. Output yang kedua dari kendali fuzzy sistem ini adalah durasi penyalaan vacuum suction diaphragm pump yang melakukan mekanisme peristaltik terhadap level air (oWater) dalam satuan detik. Penentuan membership output air dilakukan berdasarkan perhitungan jumlah air yang diperlukan untuk mencapai set pointair. Perhitungan dilakukan berdasarkan spesifikasi debit suction pump sebesar 2 L/Menit. Panjang dan lebar reservoir adalah $378 \mathrm{~mm} \times 241 \mathrm{~mm}$. Set point level (tinggi) air adalah $110 \mathrm{~mm}$, atau volume sebesar 10 Liter. Membership oNutrient terdiri dari Z = Zero, S = Small, M = Medium, dan LG $=$ Large. Membership function output nutrisi dan level air terdapat pada Gambar 8.

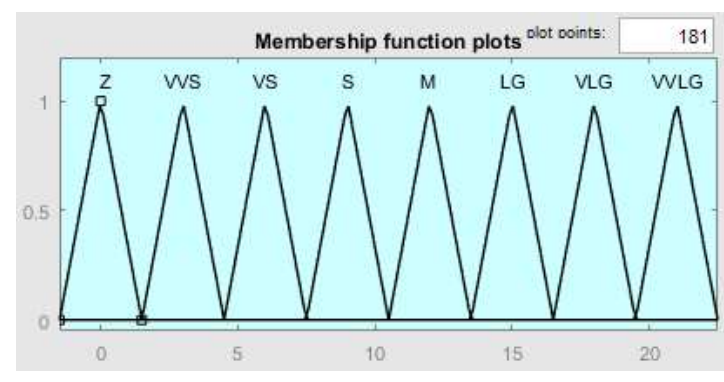

(a)

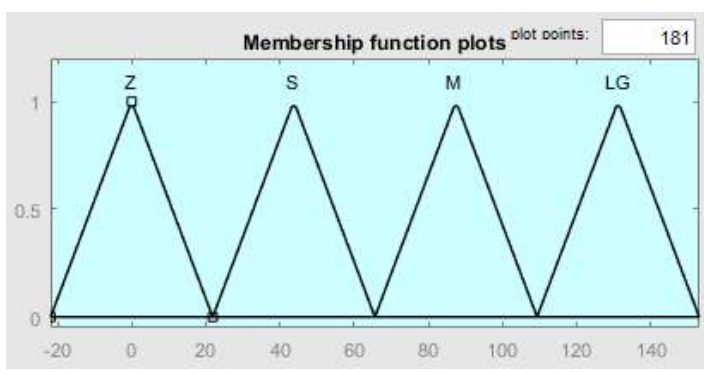

(b)

Gambar 8. Membership Function Output (a) Nutrisi dan (b) Level Air

Berdasarkan input dan output yang telah ditentukan, maka fuzzy mapping rules dapat dirancang. Mapping tersebut dirancang untuk menentukan perlakuan yang harus diberikan terhadap output nutrisi dan output level air berdasarkan input yang diterima. Fuzzy mapping rules ditunjukkan pada Tabel 1. 
Tabel 1. (a) Nutrient Output Fuzzy Mapping Rules dan (b) Water Output Fuzzy Mapping

(a)

\begin{tabular}{|c|c|c|c|c|c|}
\hline \multirow{2}{*}{$\begin{array}{c}\text { Nutrient } \\
\text { Output } \\
\text { Mapping }\end{array}$} & \multicolumn{4}{|c|}{ Nutrient } \\
\cline { 3 - 6 } & L & M & E & H \\
\hline \multirow{4}{*}{ Water } & L & VVLG & VVLG & VLG & LG \\
\cline { 2 - 6 } & M & VLG & LG & M & S \\
\cline { 2 - 6 } & E & VS & VVS & Z & Z \\
\cline { 2 - 6 } & H & VS & VVS & Z & Z \\
\hline
\end{tabular}

(b)

\begin{tabular}{|c|c|c|c|c|c|}
\hline \multirow{2}{*}{\multicolumn{2}{|c|}{$\begin{array}{c}\text { Water Output } \\
\text { Mapping }\end{array}$}} & \multicolumn{4}{|c|}{ Nutrient } \\
\hline & & \multirow{2}{*}{$\begin{array}{c}\text { L } \\
\text { LG }\end{array}$} & \multirow{2}{*}{$\begin{array}{c}\text { M } \\
\text { LG }\end{array}$} & \multirow{2}{*}{$\begin{array}{c}\mathbf{E} \\
\text { LG }\end{array}$} & \multirow{2}{*}{$\begin{array}{c}\mathbf{H} \\
\text { LC }\end{array}$} \\
\hline \multirow{4}{*}{ Water } & $\mathbf{L}$ & & & & \\
\hline & M & M & M & M & M \\
\hline & $\mathbf{E}$ & $\mathrm{Z}$ & Z & $\mathrm{Z}$ & $\mathrm{S}$ \\
\hline & $\mathbf{H}$ & $\mathrm{Z}$ & Z & $\mathrm{Z}$ & Z \\
\hline
\end{tabular}

\section{HASIL DAN PEMBAHASAN}

\subsection{Hasil Aktualisasi Perancangan}

Sistem yang telah dirancang dan dibuat pemodelannya, dapat direalisasikan yang ditunjukkan pada Gambar 9. Sistem yang telah diintegrasikan dapat diuji dan dianalisa sehingga ketercapaian sistem dapat dibandingkan dengan tuntutan sistem. Aplikasi yang dibuat pada Android Blynk berhasil menampilkan pemantauan pembacaan dari sensor nutrisi, sensor ketinggian (level air), dan sensor $\mathrm{pH}$. Pengontrolan, dapat dilakukan dalam dua mode pengaturan set point yaitu melalui database atau slider.
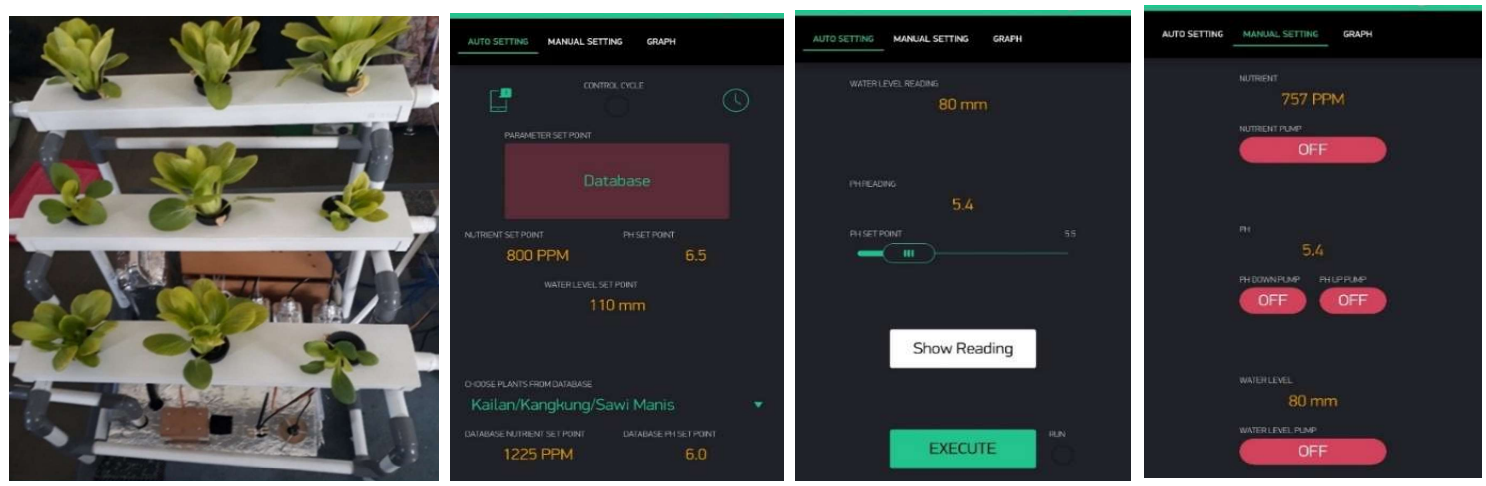

Gambar 9. Hasil Aktualisasi Plant Hidroponik dan Tampilan aplikasi

\subsection{Pengujian Sensor}

Pengujian sensor nutrisi dilakukan dengan membandingkan pembacaan nilai PPM dari sensor TDS dengan TDS meter yang ditunjukkan pada Tabel 2. Perlakuan yang diberikan saat pengujian merupakan penambahan larutan AB mix yang dapat meningkatkan kadar PPM pada 2 liter air. Berdasarkan Tabel 2 tersebut, persamaan polynomial dapat mengurangi error dengan adjusting sehingga didapat nilai rata-rata error terbaru sebesar 2,78 \% atau akurasi sebesar $97,22 \%$.

\subsection{Pengujian Pengontrolan Sistem}

Pengontrolan utama sistem dilakukan menggunakan fuzzy logic untuk mengatur nilai nutrisi dan level air. Pengontrolan fuzzy logic menggunakan dua input, yaitu level air dan kadar nutrisi, untuk mengatur dan menghasilkan dua output, yaitu durasi aktivasi motor pompa air dan durasi aktivasi motor pompa nutrisi A serta nutrisi B dalam satuan detik. Pengujian kendali fuzzy logic terdapat pada Tabel 3. 
Tabel 2. Pengujian Akurasi Sensor Nutrisi (TDS Sensor)

\begin{tabular}{|c|c|c|c|c|c|c|c|c|c|}
\hline \multirow[b]{2}{*}{ No. } & \multirow[b]{2}{*}{$\begin{array}{c}\text { Pekatan AB } \\
{[\mathrm{mL}]}\end{array}$} & \multirow[b]{2}{*}{$\begin{array}{c}\text { TDS Meter } \\
\text { [PPM] }\end{array}$} & \multirow[b]{2}{*}{ ADC } & \multicolumn{3}{|c|}{ Tanpa Persamaan Polinomial } & \multicolumn{3}{|c|}{ Dengan Persamaan Polinomial } \\
\hline & & & & $\begin{array}{c}\text { TDS Sensor } \\
\text { [PPM] }\end{array}$ & $\begin{array}{l}\text { Error } \\
{[\%]}\end{array}$ & $\begin{array}{c}\text { Akurasi } \\
\text { [\%] }\end{array}$ & $\begin{array}{c}\text { TDS Sensor } \\
\text { [PPM] }\end{array}$ & $\begin{array}{l}\text { Error } \\
{[\%]}\end{array}$ & $\begin{array}{c}\text { Akurasi } \\
{[\%]}\end{array}$ \\
\hline 1 & 6.5 & 562 & 286 & 598 & 6.41 & 93.59 & 624 & 11.03 & 88.97 \\
\hline 2 & 7 & 602 & 292 & 616 & 2.33 & 97.67 & 600 & 0.33 & 99.67 \\
\hline 3 & 7.5 & 620 & 298 & 632 & 1.94 & 98.06 & 601 & 3.06 & 96.94 \\
\hline 4 & 8 & 667 & 304 & 645 & 3.30 & 96.70 & 627 & 6.00 & 94.00 \\
\hline 5 & 8.5 & 718 & 310 & 662 & 7.80 & 92.20 & 677 & 5.71 & 94.29 \\
\hline 6 & 9 & 767 & 314 & 673 & 12.26 & 87.74 & 724 & 5.61 & 94.39 \\
\hline 7 & 9.5 & 814 & 318 & 684 & 15.97 & 84.03 & 782 & 3.93 & 96.07 \\
\hline 8 & 10 & 859 & 322 & 695 & 19.09 & 80.91 & 851 & 0.93 & 99.07 \\
\hline 9 & 10.5 & 906 & 325 & 704 & 22.30 & 77.70 & 910 & 0.44 & 99.56 \\
\hline 10 & 11 & 953 & 328 & 713 & 25.18 & 74.82 & 975 & 2.31 & 97.69 \\
\hline 11 & 11.5 & 1003 & 330 & 719 & 28.32 & 71.68 & 1022 & 1.89 & 98.11 \\
\hline 12 & 12 & 1044 & 332 & 725 & 30.56 & 69.44 & 1071 & 2.59 & 97.41 \\
\hline 13 & 12.5 & 1084 & 334 & 731 & 32.56 & 67.44 & 1123 & 3.60 & 96.40 \\
\hline 14 & 13 & 1133 & 336 & 737 & 34.95 & 65.05 & 1178 & 3.97 & 96.03 \\
\hline 15 & 13.5 & 1178 & 337 & 740 & 37.18 & 62.82 & 1207 & 2.46 & 97.54 \\
\hline 16 & 14 & 1226 & 338 & 743 & 39.40 & 60.60 & 1236 & 0.82 & 99.18 \\
\hline 17 & 14.5 & 1276 & 340 & 749 & 41.30 & 58.70 & 1297 & 1.65 & 98.35 \\
\hline 18 & 15 & 1321 & 342 & 755 & 42.85 & 57.15 & 1360 & 2.95 & 97.05 \\
\hline 19 & 15.5 & 1368 & 343 & 758 & 44.59 & 55.41 & 1392 & 1.75 & 98.25 \\
\hline 20 & 16 & 1407 & 344 & 761 & 45.91 & 54.09 & 1426 & 1.35 & 98.65 \\
\hline 21 & 16.5 & 1470 & 345 & 764 & 48.03 & 51.97 & 1460 & 0.68 & 99.32 \\
\hline 22 & 17 & 1508 & 346 & 767 & 49.14 & 50.86 & 1494 & 0.93 & 99.07 \\
\hline 23 & 17.5 & 1549 & 347 & 770 & 50.29 & 49.71 & 1530 & 1.23 & 98.77 \\
\hline 24 & 18 & 1597 & 348 & 774 & 51.53 & 48.47 & 1566 & 1.94 & 98.06 \\
\hline 25 & 18.5 & 1640 & 349 & 777 & 52.62 & 47.38 & 1603 & 2.26 & 97.74 \\
\hline 26 & 19 & 1687 & 350 & 780 & 53.76 & 46.24 & 1640 & 2.79 & 97.21 \\
\hline \multicolumn{4}{|c|}{ Rata-rata [\%] } & & 30.75 & 69.25 & & 2.78 & 97.22 \\
\hline
\end{tabular}

Tabel 3. Pengujian Kendali Fuzzy Logic

\begin{tabular}{|c|c|c|c|c|c|c|c|c|c|c|}
\hline \multirow[b]{2}{*}{ No. } & \multicolumn{2}{|c|}{ Input } & \multicolumn{4}{|c|}{ Output Nutrisi } & \multicolumn{4}{|c|}{ Output Air } \\
\hline & $\begin{array}{c}\text { Offset } \\
\text { Nutrisi } \\
\text { [PPM] }\end{array}$ & $\begin{array}{c}\text { Level } \\
\text { Air } \\
{[\mathrm{mm}]}\end{array}$ & $\begin{array}{c}\text { Output } \\
\text { MatLab } \\
\text { [s] }\end{array}$ & $\begin{array}{c}\text { Output } \\
\text { Sistem } \\
\text { [s] }\end{array}$ & $\begin{array}{l}\text { Error } \\
{[\%]}\end{array}$ & $\begin{array}{c}\text { Akurasi } \\
\text { [\%] }\end{array}$ & $\begin{array}{c}\text { Output } \\
\text { Sistem } \\
\text { [s] }\end{array}$ & $\begin{array}{l}\text { Output } \\
\text { Air [s] }\end{array}$ & $\begin{array}{l}\text { Error } \\
{[\%]}\end{array}$ & $\begin{array}{c}\text { Akurasi } \\
\text { [\%] }\end{array}$ \\
\hline 1 & -223 & \multirow{5}{*}{28} & 15 & 15 & 0.00 & 100.00 & 131 & 131.19 & 0.15 & 99.85 \\
\hline 2 & -139 & & 15 & 15 & 0.00 & 100.00 & 131 & 131.19 & 0.15 & 99.85 \\
\hline 3 & -54 & & 13.6 & 13.62 & 0.15 & 99.85 & 131 & 131.19 & 0.15 & 99.85 \\
\hline 4 & +72 & & 10.8 & 10.92 & 1.11 & 98.89 & 131 & 131.19 & 0.15 & 99.85 \\
\hline 5 & +217 & & 9 & 9 & 0.00 & 100.00 & 131 & 131.19 & 0.15 & 99.85 \\
\hline 6 & -211 & \multirow{5}{*}{71} & 13.4 & 13.31 & 0.67 & 99.33 & 107 & 106.59 & 0.38 & 99.62 \\
\hline 7 & -151 & & 11.9 & 11.89 & 0.08 & 99.92 & 108 & 107.65 & 0.32 & 99.68 \\
\hline 8 & -48 & & 10.3 & 10.27 & 0.29 & 99.71 & 108 & 107.44 & 0.52 & 99.48 \\
\hline 9 & +102 & & 7.35 & 7.36 & 0.14 & 99.86 & 108 & 107.65 & 0.32 & 99.68 \\
\hline 10 & +229 & & 5.75 & 5.63 & 2.09 & 97.91 & 107 & 106.59 & 0.38 & 99.62 \\
\hline 11 & -235 & \multirow{5}{*}{93} & 9.13 & 9.19 & 0.66 & 99.34 & 45.5 & 46.47 & 2.13 & 97.87 \\
\hline 12 & -163 & & 7.73 & 7.83 & 1.29 & 98.71 & 45.5 & 46.47 & 2.13 & 97.87 \\
\hline 13 & -60 & & 4.69 & 4.77 & 1.71 & 98.29 & 45.5 & 46.47 & 2.13 & 97.87 \\
\hline 14 & +108 & & 2.99 & 2.99 & 0.00 & 100.00 & 45.2 & 45.61 & 0.91 & 99.09 \\
\hline 15 & +223 & & 1.57 & 1.59 & 1.27 & 98.73 & 66.5 & 66.96 & 0.69 & 99.31 \\
\hline 16 & -217 & \multirow{5}{*}{115} & 6 & 6 & 0.00 & 100.00 & 0 & 0 & 0.00 & 100.00 \\
\hline 17 & -157 & & 4.64 & 4.71 & 1.51 & 98.49 & 0 & 0 & 0.00 & 100.00 \\
\hline 18 & -42 & & 1.34 & 1.27 & 5.22 & 94.78 & 0 & 0 & 0.00 & 100.00 \\
\hline 19 & +84 & & 0 & 0 & 0.00 & 100.00 & 19.5 & 18.37 & 5.79 & 94.21 \\
\hline 20 & +214 & & 0 & 0 & 0.00 & 100.00 & 27.6 & 30.07 & 8.95 & 91.05 \\
\hline 21 & -216 & \multirow{5}{*}{133} & 6 & 6 & 0.00 & 100.00 & 0 & 0 & 0.00 & 100.00 \\
\hline 22 & -138 & & 4.25 & 4.14 & 2.59 & 97.41 & 0 & 0 & 0.00 & 100.00 \\
\hline 23 & -54 & & 1.58 & 1.62 & 2.53 & 97.47 & 0 & 0 & 0.00 & 100.00 \\
\hline 24 & +127 & & 0 & 0 & 0.00 & 100.00 & 0 & 0 & 0.00 & 100.00 \\
\hline 25 & +226 & & 0 & 0 & 0.00 & 100.00 & 0 & 0 & 0.00 & 100.00 \\
\hline \multicolumn{3}{|c|}{ ta-rata [\%] } & & & 0.85 & 99.15 & & & $\begin{array}{l}1.02 \\
\end{array}$ & 98.98 \\
\hline
\end{tabular}


Pengujian pada Tabel 3 dilakukan dengan input kadar nutrisi dan level air yang bervariatif yang meliputi seluruh block dari membership function pada fuzzy mapping dan dibandingkan dengan output pada pemodelan fuzzy logic MatLab. Hasil pengujian kendali fuzzy logic dibandingkan dengan hasil output fuzzy pada MatLab menunjukkan akurasi yang tinggi sebesar $98.98 \%$.

Selanjutnya dilakukan pengujian hasil pencampuran nutrisi berdasarkan kendali fuzzy logic dengan melakukan perbandingan antara kadar nutrisi dan level air terhadap set point yang disajikan pada Tabel 4. Input kendali nutrisi berupa pembacaan level air dan offset nutrisi. Offset nutrisi merupakan selisih nilai pembacaan sensor nutrisi terhadap set point nutrisi. Set point nutrisi yang digunakan adalah 1225 PPM. Sedangkan Pembacaan level air merupakan pembacaan di reservoir larutan nutrisi untuk penyiraman tanaman. Set point level air yang digunakan adalah $110 \mathrm{~mm}$.

Tabel 4. Pengujian Pengontrolan Sistem terhadap Ketercapaian Set Point

\begin{tabular}{|c|c|c|c|c|c|c|c|c|c|c|}
\hline \multirow[b]{2}{*}{ No. } & \multicolumn{2}{|c|}{ Input } & \multirow[b]{2}{*}{$\begin{array}{c}\text { Set } \\
\text { Point } \\
\text { Nutrisi } \\
\text { [PPM] }\end{array}$} & \multicolumn{3}{|c|}{ Output Nutrisi } & \multirow[b]{2}{*}{$\begin{array}{l}\text { Set } \\
\text { Point } \\
\text { Air } \\
{[\mathrm{mm}]}\end{array}$} & \multicolumn{3}{|c|}{ Output Air } \\
\hline & $\begin{array}{c}\text { Offset } \\
\text { Nutrisi } \\
\text { [PPM] }\end{array}$ & $\begin{array}{c}\text { Level } \\
\text { Air } \\
{[\mathrm{mm}]}\end{array}$ & & $\begin{array}{c}\text { Nutrisi Setelah } \\
\text { Pencampuran } \\
\text { [PPM] }\end{array}$ & $\begin{array}{l}\text { Error } \\
{[\%]}\end{array}$ & $\begin{array}{c}\text { Akurasi } \\
{[\%]}\end{array}$ & & $\begin{array}{c}\text { Level Air } \\
\text { Setelah } \\
\text { Pencampuran } \\
{[\mathrm{mm}]}\end{array}$ & $\begin{array}{l}\text { Error } \\
{[\%]}\end{array}$ & $\begin{array}{c}\text { Akurasi } \\
{[\%]}\end{array}$ \\
\hline 1 & +321 & 55 & \multirow{20}{*}{1225} & 1328 & 8.41 & 91.59 & \multirow{20}{*}{110} & 112 & 1.82 & 98.18 \\
\hline 2 & -362 & 56 & & 1303 & 6.37 & 93.63 & & 114 & 3.64 & 96.36 \\
\hline 3 & -88 & 58 & & 1232 & 0.57 & 99.43 & & 111 & 0.91 & 99.09 \\
\hline 4 & -107 & 74 & & 1232 & 0.57 & 99.43 & & 106 & 3.64 & 96.36 \\
\hline 5 & +161 & 74 & & 1270 & 3.67 & 96.33 & & 111 & 0.91 & 99.09 \\
\hline 6 & -107 & 76 & & 1251 & 2.12 & 97.88 & & 107 & 2.73 & 97.27 \\
\hline 7 & +281 & 78 & & 1348 & 10.04 & 89.96 & & 107 & 2.73 & 97.27 \\
\hline 8 & -199 & 85 & & 1232 & 0.57 & 99.43 & & 115 & 4.55 & 95.45 \\
\hline 9 & -107 & 89 & & 1323 & 8.00 & 92.00 & & 113 & 2.73 & 97.27 \\
\hline 10 & +123 & 106 & & 1289 & 5.22 & 94.78 & & 109 & 0.91 & 99.09 \\
\hline 11 & -51 & 110 & & 1213 & 0.98 & 99.02 & & 110 & 0.00 & 100.00 \\
\hline 12 & -32 & 110 & & 1213 & 0.98 & 99.02 & & 110 & 0.00 & 100.00 \\
\hline 13 & -236 & 117 & & 1175 & 4.08 & 95.92 & & 118 & 7.27 & 92.73 \\
\hline 14 & +64 & 117 & & 1270 & 3.67 & 96.33 & & 123 & 11.82 & 88.18 \\
\hline 15 & -125 & 128 & & 1175 & 4.08 & 95.92 & & 129 & 17.27 & 82.73 \\
\hline 16 & -88 & 129 & & 1213 & 0.98 & 99.02 & & 130 & 18.18 & 81.82 \\
\hline 17 & -218 & 130 & & 1175 & 4.08 & 95.92 & & 130 & 18.18 & 81.82 \\
\hline 18 & -12 & 133 & & 1323 & 8.00 & 92.00 & & 133 & 20.91 & 79.09 \\
\hline 19 & +103 & 135 & & 1328 & 8.41 & 91.59 & & 135 & 22.73 & 77.27 \\
\hline 20 & +201 & 139 & & 1426 & 16.41 & 83.59 & & 139 & 26.36 & 73.64 \\
\hline \multicolumn{3}{|c|}{ Rata-rata [\%] } & & & 4.86 & 95.14 & & & 8.36 & 91.64 \\
\hline
\end{tabular}

Pengujian pada Tabel 4 menggunakan dua puluh data input yang mewakili kondisi-kondisi dengan level air dan kadar nutrisi yang berbeda-beda sebelum terjadinya pencampuran menggunakan fuzzy logic. Dua puluh data tersebut menjadi input fuzzy yang tersebar di area fuzzy mapping rules pada Tabel 1 (a) dan (b) untuk menghasilkan output durasi aktivasi pompa nutrisi dan/atau pompa air untuk mencapai set point nutrisi dan level air pada reservoir. Kolom "Nutrisi Setelah Pencampuran [PPM]" dan "Level Air Setelah Pencampuran [mm]" menyatakan data pembacaan pertama kadar nutrisi setelah proses penambahan nutrisi dan/atau air dan pengadukan melalui sirkulasi pompa reservoir selama 300 detik (delay 5 menit) seperti pada diagram alir sistem. Berdasarkan data Tabel 4, dapat disimpulkan bahwa pengujian kendali kadar nutrisi dan level air setelah proses pencampuran berdasarkan fuzzy logic yang dibandingkan dengan nilai set point memiliki keberhasilan sebesar 95,14\% untuk nutrisi dan $91,64 \%$ untuk air. Kendali tersebut memiliki rata-rata error sebesar 4,86 \% untuk nutrisi dan $8,36 \%$ untuk air dari dua puluh kali percobaan dengan input fuzzy yang bervariasi pada fuzzy mapping rules. Selanjutnya dilakukan pengujian respon sistem pada nilai input fuzzy 1007 PPM untuk kadar nutrisi dan 90 mm untuk level air yang diperlihatkan pada Gambar 10. 


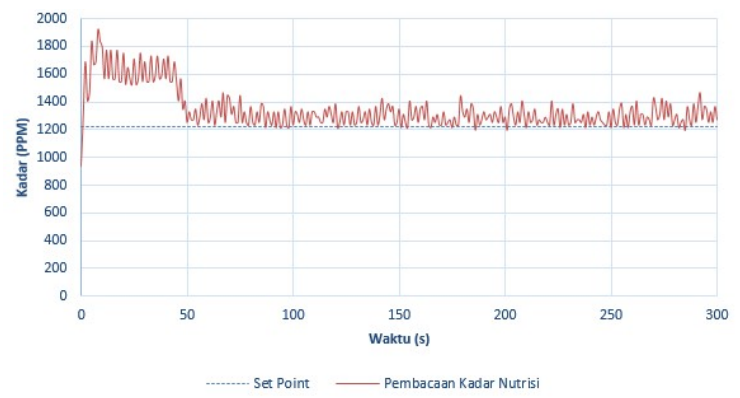

(a)

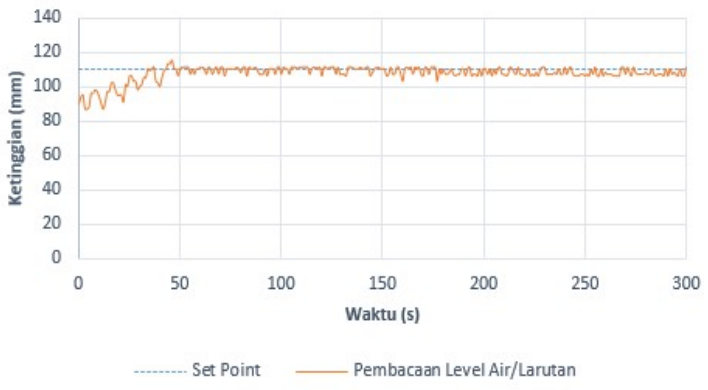

(b)

Gambar 10. Grafik Respon (a) Kadar Nutrisi dan (b) Level Air/Larutan

Data pembacaan untuk menguji nilai response time dalam satuan detik (s) diambil selama 300 detik pada saat terjadinya sirkulasi reservoir. Respon waktu kendali kadar nutrisi pada Gambar 10(a), menunjukkan sistem mencapai settling time pada 50 detik dengan maksimum overshoot sebesar 1923 PPM atau 57\%\%. Pembacaan akhir masa sirkulasi pada detik ke 300 adalah 1270 PPM. Keadaan steady dimulai dari detik ke 50 hingga 300 dengan kisaran pembacaan nutrisi sebesar 1195 - 1466 PPM. Sistem kendali kadar nutrisi memiliki error steady state sebesar 5,9\%. Sementara itu, respon waktu kendali level air larutan pada reservoir yang ditunjukkan Gambar 10(b), menunjukkan sistem mencapai settling time pada 54 detik dengan maksimum overshoot sebesar $115 \mathrm{~mm}$ atau 4,5\%. Pembacaan akhir masa sirkulasi pada detik ke 300 adalah $111 \mathrm{~mm}$. Keadaan steady dimulai dari detik ke 54 hingga 300 dengan kisaran pembacaan 103 - $111 \mathrm{~mm}$. Sistem kendali kadar level air memiliki error steady state sebesar $1,7 \%$.

\subsection{Pengujian Pertumbuhan Tanaman}

Pengujian pertumbuhan tanaman dilakukan dengan membandingkan pertumbuhan 18 tanaman pakcoy yang disemai secara bersamaan, mendapatkan sumber cahaya yang sama, diberikan nutrisi awal dengan PPM yang sama, tetapi 9 tanaman diberikan sistem kendali nutrisi dengan fuzzy logic sementara 9 tanaman lagi tidak dilakukan kendali nutrisi fuzzy logic.

Berdasarkan data pada Tabel 5, dapat dilihat bahwa warna tanaman pakcoy pada hari terakhir pengamatan memiliki perbedaan. Tanaman menjadi kekuningan akibat perbedaan perlakuan pada penjagaan kadar nutrisi, yakni tidak menggunakan sistem kendali nutrisi. Sementara tanaman dengan sistem kendali nutrisi menggunakan fuzzy logic tetap berwarna kehijauan.

Pengamatan pertumbuhan dilakukan selama 14 hari dengan mengambil ketinggian dan jumlah daun masing-masing tanaman setiap hari pada pukul 5 sore. Berikut merupakan data pengujian pertumbuhan tanaman yang nutrisinya dijaga menggunakan sistem kendali fuzzy logic pada Tabel 6. 
Tabel 5. Pengujian Pertumbuhan Tanaman

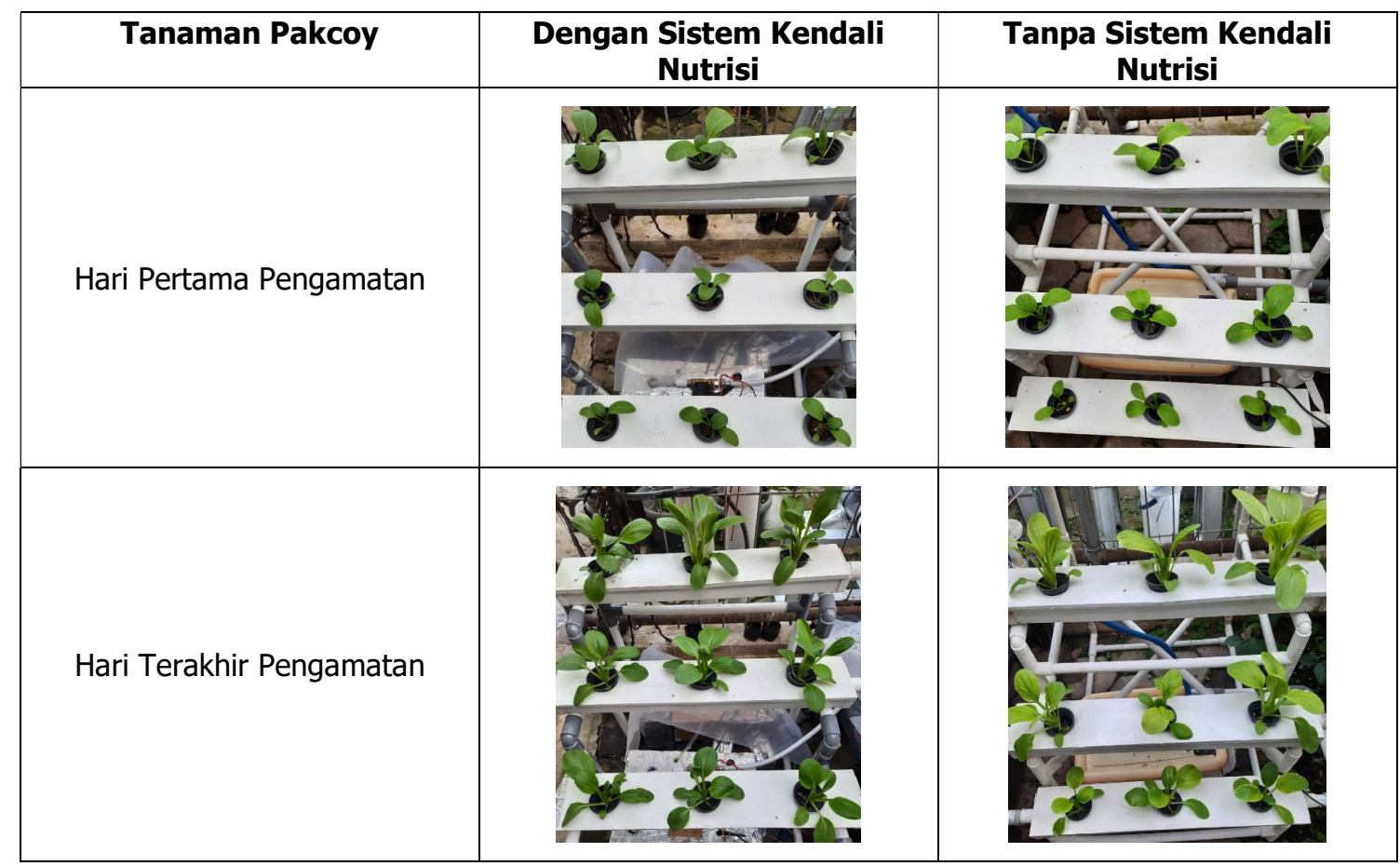

Tabel 6. Pertumbuhan Tanaman dengan Sistem Kendali Nutrisi

\begin{tabular}{|c|c|c|c|c|c|c|c|c|c|c|c|c|c|c|c|c|c|c|}
\hline \multirow{2}{*}{$\begin{array}{c}\text { Hari } \\
\text { ke- }\end{array}$} & \multicolumn{9}{|c|}{ Tinggi Tanaman $(\mathrm{cm})$} & \multicolumn{9}{|c|}{ Jumlah Daun } \\
\hline & T1 & T2 & T3 & T4 & T5 & T6 & T7 & T8 & T9 & T1 & T2 & T3 & T4 & T5 & T6 & T7 & T8 & T9 \\
\hline 1 & 8 & 6 & 6,5 & 7 & 8 & 6 & 9 & 8 & 6 & 5 & 6 & 5 & 6 & 6 & 6 & 6 & 8 & 6 \\
\hline 2 & 8 & 6,5 & 7 & 7 & 8 & 6 & 10 & 8,5 & 6,5 & 6 & 6 & 6 & 6 & 7 & 7 & 7 & 9 & 7 \\
\hline 3 & 8 & 6,5 & 7,5 & 7 & 8 & 6,5 & 10 & 8,5 & 7 & 6 & 7 & 6 & 7 & 7 & 7 & 8 & 9 & 7 \\
\hline 4 & 8,5 & 7 & 8 & 7 & 8 & 7 & 10,5 & 8,5 & 7 & 6 & 7 & 6 & 8 & 8 & 8 & 8 & 10 & 8 \\
\hline 5 & 9 & 7,5 & 8,5 & 7,5 & 8,5 & 7,5 & 10,5 & 9 & 7,5 & 6 & 8 & 7 & 8 & 8 & 8 & 9 & 10 & 8 \\
\hline 6 & 9,5 & 8 & 9 & 8 & 8,5 & 8,5 & 11 & 10 & 8,5 & 7 & 8 & 7 & 8 & 8 & 8 & 10 & 10 & 9 \\
\hline 7 & 9,5 & 9 & 9,5 & 9 & 9,5 & 9,5 & 11,5 & 12 & 10 & 8 & 9 & 8 & 9 & 9 & 9 & 10 & 10 & 9 \\
\hline 8 & 10 & 10 & 10 & 10 & 10 & 10,5 & 12 & 13 & 11 & 8 & 9 & 8 & 9 & 9 & 10 & 10 & 11 & 10 \\
\hline 9 & 10,5 & 10 & 10 & 11 & 10,5 & 11 & 12 & 13,5 & 12 & 8 & 10 & 8 & 10 & 9 & 10 & 11 & 11 & 10 \\
\hline 10 & 11,5 & 10,5 & 10,5 & 11,5 & 11,5 & 11 & 13 & 13,5 & 12,5 & 9 & 10 & 8 & 10 & 10 & 11 & 11 & 12 & 11 \\
\hline 11 & 11,5 & 11 & 11,5 & 11,5 & 12 & 13 & 13 & 15 & 15 & 9 & 10 & 9 & 10 & 10 & 11 & 11 & 13 & 11 \\
\hline 12 & 11,5 & 11 & 12,5 & 11,5 & 13 & 14 & 13,5 & 15,5 & 15,5 & 10 & 11 & 9 & 11 & 10 & 11 & 11 & 13 & 11 \\
\hline 13 & 12 & 11 & 13 & 12 & 13 & 14 & 14,5 & 16 & 15,5 & 10 & 11 & 10 & 11 & 11 & 11 & 12 & 14 & 12 \\
\hline 14 & 12,5 & 11,5 & 14 & 15 & 13 & 15 & 14,5 & 17 & 16 & 11 & 12 & 10 & 12 & 12 & 12 & 12 & 15 & 13 \\
\hline
\end{tabular}

Berdasarkan Tabel 6, didapatkan beberapa data yang dapat diambil dari pengamatan tanaman pakcoy selama 14 hari dengan sistem kendali nutrisi. Tanaman terpendek di hari terakhir adalah $11,5 \mathrm{~cm}$ dan tanaman tertinggi adalah $17 \mathrm{~cm}$. Jumlah daun paling sedikit di hari terakhir adalah 10 helai daun dan jumlah daun terbanyak di hari terakhir adalah 15 helai daun. Ratarata ketinggian 9 tanaman di hari pertama adalah 7,25 cm sementara di hari terakhir adalah $15 \mathrm{~cm}$. Rata-rata penambahan tinggi dari hari pertama ke terakhir adalah 7, $75 \mathrm{~cm}$ sementara rata-rata penambahan jumlah daun dari hari pertama ke hari terakhir adalah 6 helai daun. Sedangkan data pengujian pertumbuhan tanaman yang tidak menggunakan kendali nutrisi terdapat pada Tabel 7. 
Tabel 7. Pertumbuhan Tanaman Tanpa Sistem Kendali Nutrisi

\begin{tabular}{|c|c|c|c|c|c|c|c|c|c|c|c|c|c|c|c|c|c|c|}
\hline \multirow{3}{*}{$\begin{array}{c}\text { Hari } \\
\text { ke- }\end{array}$} & & & & & & & & & & & & & & & & & & \\
\hline & \multicolumn{9}{|c|}{ Tinggi Tanaman $(\mathrm{cm})$} & \multicolumn{9}{|c|}{ Jumlah Daun } \\
\hline & T10 & T11 & T12 & T13 & T14 & T15 & T16 & T17 & T18 & T10 & T11 & T12 & T13 & T14 & T15 & T16 & T17 & T18 \\
\hline 1 & 6,5 & 8 & 8 & 8 & 7 & 9 & 7 & 7 & 9 & 4 & 6 & 6 & 7 & 5 & 5 & 5 & 5 & 7 \\
\hline 2 & 6,5 & 8 & 8 & 8 & 8 & 9 & 7,5 & 7 & 10 & 4 & 7 & 7 & 8 & 6 & 6 & 6 & 6 & 7 \\
\hline 3 & 7 & 8,5 & 10 & 8,5 & 8 & 10 & 8 & 7,5 & 10,5 & 4 & 7 & 7 & 8 & 6 & 7 & 7 & 7 & 8 \\
\hline 4 & 7 & 8,5 & 10 & 9 & 8 & 10 & 8 & 8 & 11 & 5 & 7 & 8 & 8 & 6 & 8 & 8 & 8 & 9 \\
\hline 5 & 7 & 9 & 10 & 9,5 & 8,5 & 10 & 8 & 8,5 & 11,5 & 5 & 7 & 8 & 8 & 7 & 9 & 8 & 8 & 9 \\
\hline 6 & 7,5 & 9 & 11 & 10 & 8,5 & 10,5 & 8,5 & 9 & 12,5 & 6 & 8 & 8 & 9 & 8 & 9 & 9 & 8 & 9 \\
\hline 7 & 7,5 & 9 & 11 & 11 & 9 & 10,5 & 10 & 10 & 13,5 & 6 & 8 & 9 & 10 & 8 & 9 & 9 & 9 & 10 \\
\hline 8 & 9 & 10 & 11 & 11,5 & 9 & 12 & 10 & 11 & 14 & 7 & 9 & 9 & 10 & 8 & 10 & 10 & 9 & 11 \\
\hline 9 & 9 & 10 & 12 & 11,5 & 9,5 & 12 & 10 & 11 & 14,5 & 7 & 9 & 9 & 11 & 8 & 10 & 10 & 9 & 11 \\
\hline 10 & 9 & 10 & 12 & 12,5 & 10 & 12 & 11 & 11 & 14,5 & 7 & 9 & 9 & 11 & 8 & 11 & 11 & 9 & 12 \\
\hline 11 & 9 & 10,5 & 12,5 & 12,5 & 10 & 12 & 11 & 11 & 16 & 7 & 10 & 9 & 12 & 9 & 11 & 11 & 9 & 13 \\
\hline 12 & 9,5 & 10,5 & 12,5 & 13 & 10 & 13 & 11 & 11 & 16,5 & 7 & 10 & 9 & 12 & 9 & 11 & 11 & 9 & 13 \\
\hline 13 & 10 & 11 & 12,5 & 13,5 & 10 & 13,5 & 12,5 & 12 & 17 & 8 & 10 & 9 & 12 & 9 & 12 & 12 & 10 & 13 \\
\hline 14 & 10,5 & 12,5 & 13 & 14 & 11 & 14 & 13,5 & 13 & 17 & 8 & 10 & 10 & 13 & 10 & 12 & 12 & 10 & 13 \\
\hline
\end{tabular}

Berdasarkan data Tabel 7, didapatkan beberapa data yang dapat diambil dari pengamatan tanaman pakcoy selama 14 hari tanpa sistem kendali nutrisi. Tanaman terpendek di hari terakhir adalah $10,5 \mathrm{~cm}$ dan tanaman tertinggi adalah $17 \mathrm{~cm}$. Jumlah daun paling sedikit di hari terakhir adalah 8 helai daun dan jumlah daun terbanyak di hari terakhir adalah 13 helai daun. Rata-rata ketinggian 9 tanaman di hari pertama adalah 7,88 cm sementara di hari terakhir adalah $13,67 \mathrm{~cm}$. Rata-rata penambahan tinggi dari hari pertama ke terakhir adalah $5,79 \mathrm{~cm}$ sementara rata-rata penambahan jumlah daun dari hari pertama ke hari terakhir adalah 5 helai daun. Data komparasi pertumbuhan tanaman dengan sistem kendali nutrisi dan tanpa kendali nutrisi terdapat pada Tabel 8.

Tabel 8. Komparasi Pertumbuhan Tanaman

\begin{tabular}{|c|l|c|c|}
\hline No & \multicolumn{1}{|c|}{ Parameter Analisis } & $\begin{array}{c}\text { Tanpa Kendali } \\
\text { Nutrisi }\end{array}$ & $\begin{array}{c}\text { Dengan Kendali } \\
\text { Nutrisi }\end{array}$ \\
\hline \multirow{3}{*}{1} & Rata-rata ketinggian hari pertama pengamatan $(\mathrm{cm})$ & 7,88 & 7,25 \\
\cline { 2 - 4 } & Rata-rata ketinggian hari terakhir pengamatan $(\mathrm{cm})$ & 13,67 & 15 \\
\cline { 2 - 4 } & Rata-rata penambahan tinggi (cm) & 5,79 & 7,75 \\
\hline \multirow{2}{*}{2} & Rata-rata jumlah daun hari pertama pengamatan (buah) & 6 & 6 \\
\cline { 2 - 4 } & Rata-rata jumlah daun hari terakhir pengamatan (buah) & 11 & 12 \\
\cline { 2 - 4 } & Rata-rata penambahan jumlah daun (buah) & 5 & 6 \\
\hline
\end{tabular}

Rata-rata pertumbuhan tanaman pada sistem hidroponik dengan menggunakan kendali nutrisi fuzzy logic menghasilkan data pertumbuhan tanaman yang lebih baik, dimana rata-rata penambahan tinggi antara sistem dengan kendali nutrisi dan tanpa kendali nutrisi memiliki perbedaan sebesar $1,96 \mathrm{~cm}$.

\section{KESIMPULAN}

Berdasarkan penelitian yang dilakukan, sistem kendali nutrisi hidroponik berbasis fuzzy logic berdasarkan objek tanam berhasil diimplementasikan menggunakan kendali fuzzy logic dengan nilai keberhasilan $95,14 \%$ untuk nutrisi dan $91,64 \%$ untuk air dalam mencapai set point. Kendali fuzzy logic memiliki nilai keberhasilan 99,15\% untuk durasi output nutrisi dan 98,98\% untuk durasi output air dari perbandingan pemodelan di MatLab. Penggunaan persamaan polinomial dapat mengurangi error pembacaan sensor TDS dari 30,75\% menjadi 2,78\%. Respon waktu pada kendali kadar nutrisi mencapai settling time pada 50 detik dan memiliki error steady state sebesar 5,9 \%. Sementara itu, respon waktu kendali level air larutan pada reservoir mencapai settling time pada 54 detik dengan error steady state sebesar $1,7 \%$. Sistem hidroponik dengan menggunakan kendali nutrisi menghasilkan pertumbuhan 
tanaman yang lebih baik, dimana rata-rata penambahan tinggi antara sistem dengan kendali nutrisi dan tanpa kendali nutrisi memiliki perbedaan sebesar $1,96 \mathrm{~cm}$.

\section{DAFTAR RUJUKAN}

Akbar, F. B., Muslim, M. A., \& Purwanto, P. (2016). Pengontrolan Nutrisi pada Sistem Tomat Hidroponik menggunakan kontroler PID. Jurnal EECCIS, 10(1), 20-25.

Crisnapati, P. N., Wardana, I. N. K., Aryanto, I. K. A. A., \& Hermawan, A. (2017). Hommons: Hydroponic Management and Monitoring System for an IOT Based NFT Farm Using Web Technology. 2017 5th International Conference on Cyber and IT Service Management (CITSM), (pp. 257-262).

Heliadi, G. G., Kirom, M. R., \& Suhendi, A. (2018). Monitoring and Control of Nutrition on NFT Hydroponic System Based on Electrical Conductivity. e-Proceeding of Engineering, (pp. 885-893).

Ibrahim, M. N. R., Solahudin, M., \& Widodo, S. (2015). Control system for nutrient solution of nutrient film technique using fuzzy logic. Telkomnika (Telecommunication Computing $\begin{array}{llll}\text { Electronics and } & \text { Control), 13(4), }\end{array}$ https://doi.org/10.12928/TELKOMNIKA.v13i4.2113

Lukito, R. B., \& Lukito, C. (2018). Development of IoT at hydroponic system using raspberry Pi. Telkomnika (Telecommunication Computing Electronics and Control), 17(2), 897906. https://doi.org/10.12928/TELKOMNIKA.V17I2.9265

Mashumah, S., Rivai, M., \& Irfansyah, A. N. (2018). Nutrient Film Technique based Hydroponic System Using Fuzzy Logic Control. Proceeding - 2018 International Seminar on Intelligent Technology and Its Application, ISITIA 2018, (pp. 387-390). https://doi.org/10.1109/ISITIA.2018.8711201

Maulido, R. N., Tobiga, O. L., \& Adimiharja, S. A. (2016). PENGARUH KEMIRINGAN PIPA PADA HIDROPONIK SISTEM NFT TERHADAP PERTUMBUHAN DAN PRODUKSI SELADA ( Lactuca sativa L . ) Effect of Pipe Slope on Growth and Production of Lettuce ( Lactuca sativa L.) in NFT Hydroponic System. Jurnal Agronida, 2(2), 62-68.

Nugroho, B. W. (2017). Jarak Tanam/Jarak Lubang untuk Tanaman Hidroponik. http://hidroponikpedia.com/jarak-tanam/

Pakzad, A. E., \& Pakzad, A. A. (2018). Fuzzy ponics: A fuzzy based system to control temperature, relative humidity, electrical conductivity and $\mathrm{PH}$ of hydroponics. International Journal of Engineering and Technology(UAE), 74.3 Special Issue 3), 308314. https://doi.org/10.14419/ijet.v7i2.7.10603 
Puspasari, I., Triwidyastuti, Y., \& Harianto, H. (2018). Otomasi Sistem Hidroponik Wick Terintegrasi pada Pembibitan Tomat Ceri. Jurnal Nasional Teknik Elektro dan Teknologi Informasi (JNTETI), ス1), 97-104. https://doi.org/10.22146/jnteti.v7i1.406

Ruengittinun, S., Phongsamsuan, S., \& Sureeratanakorn, P. (2017). Applied internet of thing for smart hydroponic farming ecosystem (HFE). Ubi-Media 2017 - Proceedings of the 10th International Conference on Ubi-Media Computing. https://doi.org/10.1109/UMEDIA.2017.8074148

Safura, S. A. El, Kirom, M. R., \& Suhendi, A. (2018). Rancang Bangun Sistem Kontrol Logika Fuzzy Pada Pengaturan Nutrient Film Technique. e-Proceeding of Engineering, 5(1), 959-966.

Setiawan, Y., Tanudjaja, H., \& Octaviani, S. (2019). Penggunaan Internet of Things (IoT) untuk Pemantauan dan Pengendalian Sistem Hidroponik. TESLA: Jurnal Teknik Elektro, 20(2), 175. https://doi.org/10.24912/tesla.v20i2.2994

Triwidyastuti, Y., Puspasari, I., \& Harianto, H. (2018). Comparison between PID and Fuzzy Controller to Hydroponic Temperature. International Conference on Information Technology Applications and Systems (ICITAS), (pp. 21-27). https://doi.org/10.1109/maes.2012.6373903

Yolanda, D., Arief, L., Sundara, T. A., Deza, M., \& Oktavia, D. (2018). Control of Electrical Conductivity for NFT Hydroponic Systems using Fuzzy Logic and Android Environment. 2018 International Conference on Information Technology Systems and Innovation, ICITSI 2018 - Proceedings, (pp. 508-514). https://doi.org/10.1109/ICITSI.2018.8695923

Yolanda, D., Hindersah, H., Hadiatna, F., \& Triawan, M. A. (2017). Implementation of realtime fuzzy logic control for NFT-based hydroponic system on Internet of Things environment. Proceedings of the 2016 6th International Conference on System Engineering and Technology, ICSET 2016, (pp. 153-159). https://doi.org/10.1109/FIT.2016.7857556 